\title{
PELATIHAN PRODUKSI KOMPOS DAN BIOGAS DI KELURAHAN LIMAU MANIS SELATAN KOTA PADANG
}

\section{Sahadi Didi Ismanto*, Anwar Kasim, Fauzan Azima, Kesuma Sayuti, Novelina, Rini, Surini Siswarjono, Novizar,Tuty Anggraini, Hasbullah, dan Netty Sri Indeswari}

\author{
Jurusan Teknologi Hasil Pertanian, Fakultas Teknologi Pertanian, Universitas Andalas \\ Kampus Limau Manis Padang-25163, Email: sahadididiismanto@gmail.com
}

\begin{abstract}
ABSTRAK
Permasalahan utama yang dihadapi kelompok tani saat ini adalah terbatasnya pengetahuan, teknologi dan peralatan produksi untuk menghasilkan kompos yang berkualitas, dengan demikian mutu kompos yang dihasilkan juga relatif masih rendah, sementara potensi yang bisa dihasilkan cukup besar. Kotoran sapi yang ada selama ini juga belum dimanfaatkan sebagai sumber biogas, karena belum adanya teknologi tepat guna pembuatan biogas yang dikuasai kelompok tani. Penyelesaian masalah ditawarkan untuk dengan cara: (1) Memberikan pelatihan cara pembuatan kompos dengan memanfaatkan kotoran sapi dan kotoran ayam broiler, sisa hijauan makanan ternak dan limbah pertanian yang dihasilkan, (2) Memberikan pelatihan pembuatan starter mikroba lokal untuk mempercepat terjadinya pengomposan, (3) Memberikan pelatihan serta peragaan pembuatan biogas dari kotoran sapi, (4) Pembuatan model digester untuk produksi biogas pada skala rumah tangga dan (5) Memberikan pelatihan penguatan kelembagaan kelompok tani untuk menuju kelompok tani yang profesional. Sesuai dengan rencana kegiatan maka dapat dijelaskan target luaran adalah (a) Bahan baku kompos dan Starter yang bisa digunakan, (b) Teknik pembuatan kompos untuk menghasilkan kualitas kompos yang baik, (c) Isu pertanian berkelanjutan dan pentingnya pupuk organik, (d) Teknik mempersiapkan kompos untuk dipasarkan dan teknik memasarkan produk kompos dan (e) Peragaan pembuatan digseter untuk pembuatan biogas berbahan baku kotoran sapi untuk skala rumah tangga.
\end{abstract}

Kata kunci: Pelatihan, Produksi kompos, Biogas

PENDAHULUAN

Kelurahan Limau Manis Selatan adalah satu dari sembilan kelurahan yang ada di Kecamatan Pauh Kota Padang serta merupakan kawasan yang berada di sekitar Kampus Universitas Andalas. Terletak pada dataran paling tinggi di Kota Padang dan memiliki tipologi lahan sawah, perladangan dan hutan yang relatif luas serta memiliki sumber air yang baik. Kondisi ini menjadikan daerah ini sebagai salah satu daerah pertanian potensial di Kota Padang. Hal ini sekaligus dapat mendukung misi Kecamatan Pauh sebagai pusat pengembangan pertanian penghasil pangan dan lumbung ternak di Kota Padang.
Pengembangan pertanian organik di Kelurahan Limau Manis Selatan juga tidak terlepas dari peran dua Kelompok Tani yaitu Kelompok Tani Batu Bajolang dan Kelompok Wanita Tani Sikayan Organik. Kelompok Tani Batu Bajolang mempunyai anggota sebanyak 40 orang dan Kelompok Wanita Tani Sikayan memiliki anggota sebanyak 20 orang. Kelompok Tani Batu Bajolang mengembangkan pertanian organik di lahan-lahan pertanian terutama untuk tanaman sayur-sayuran. Sementara itu Kelompok Wanita Tan Sikayan lebih fokus mengembangkan tanaman organik untuk tanaman pekarangan dengan komoditi sayur-sayuran, saledri, bawang daun dan 
strowbery. Kedua kelompok tani ini saling bekerjasama dimana Kelompok Tani Batu Bajolang memproduksi pupuk organik dan memproduksi beberapa jenis bibit tanaman.

Jumlah sapi yang dimiliki anggota kelompok saaat ini berjumlah lebih kurang 80 ekor. Jika rata-rata 1 ekor sapi dapat menghasilkan kotoran sebanyak $15 \mathrm{~kg}$ per hari, maka dalam 1 hari akan diperoleh sebanyak lebih kurang 1.200 kg kotoran sapi basah atau lebih kurang 36 ton kotoran sapi basah per bulan. Seyogyanya kotoran sapi ini masih bisa ditambahkan dengan hijauan sisa makanan ternak yang biasanya masih tersisa antara 20 - $30 \%$ dari jumlah hijauan yang diberikan. Jika ditambahkan juga dengan limbah tanaman dalam jumlah yang sama kemudian dikeringkan dan dapat dihasilkan produk kompos, maka potensi kompos yang dihasilkan per bulannya lebih kurang 36 ton.

Belum semua kotoran sapi dan limbah hasil pertanian dapat diolah menjadi kompos, dikarenakan keterbatasan pengetahuan (teknologi) dan peralatan yang dimiliki oleh kelompok tani untuk memproduksi kompos. Jika 36 ton kompos kering bisa dihassilkan kelompok dalam 1 bulan dan harga jual kompos saat ini lebih kurang Rp. 625,-- per kg, maka potensi pendapatan dari kompos kelompok tani di daerah ini lebih kurang sebesar Rp. 22.500.000,- per bulan.

Kotoran sapi yang dihasilkan sebelum dijadikan bahan baku kompos sebetulnya masih bisa dimanfaatkan terlebih dahulu sebagai sumber biogas. Biogas bisa dikembangkan pada setiap anggota kelompok yang memiliki sapi dan biogas yang dihasilkan bisa dimanfaatkan sebagai sumber bahan bakar pada rumah masingmasing rumah anggota.

Permasalahan utama yang dihadapi kelompok saat ini adalah terbatasnya pengetahuan, teknologi dan peralatan produksi untuk menghasilkan kompos yang berkualitas. Dengan demikian mutu kompos yang dihasilkan juga relatif masih rendah, sementara potensi yang bisa dihasilkan cukup besar.

Kotoran sapi yang ada selama ini juga belum dimanfaatkan sebagai sumber biogas, karena belum adanya teknologi tepat guna pembuatan biogas yang dikuasai kelompok tani.

Disamping keterbatasan penguasaan teknologi juga belum optimalnya kelembagaan kelompok yang baru berjalan sebatas bekerjasama dalam hal teknis bertani, namun belum berkembang dalam hal pengadaan bersama dan pemasaran produk secara bersama. Dengan demikian tingkat efisiensi dalam hal biaya produksi dan biaya pemasaran belum bisa diperoleh oleh kelompok.

\section{TARGET DAN LUARAN}

Masalah sebagaimana yang dijelaskan di atas, ditawarkan untuk diselesaikan 
dengan alternatif sebagai berikut :

1. Memberikan pelatihan cara pembuatan kompos dengan memanfaatkan kotoran sapi dan kotoran ayam broiler, sisa hijauan makanan ternak dan limbah pertanian yang dihasilkan.

2. Memberikan pelatihan pembuatan starter mikroba lokal untuk mempercepat terjadinya pengomposan.

3. Memberikan pelatihan serta peragaan pembuatan biogas dari kotoran sapi

4. Pembuatan model digester untuk produksi biogas pada skala rumah tangga.

5. Memberikan pelatihan penguatan kelembagaan kelompok tani untuk menuju kelompok tani yang profesional.

Sesuai dengan rencana kegiatan maka dapat dijelaskan target luaran adalah :

1. Bahan baku kompos dan Starter yang bisa digunakan,

2. Teknik pembuatan kompos untuk menghasilkan kualitas kompos yang baik,

3. Isu pertanian berkelanjutan dan pentingnya pupuk organik,

4. Teknik mempersiapkan kompos untuk dipasarkan dan teknik memasarkan produk kompos dan

5. Peragaan pembuatan digseter untuk pembuatan biogas berbahan baku kotoran sapi untuk skala rumah tangga.

\section{METODE PELAKSANAAN}

Guna membantu menyelesaikan masalah pada kelompok mitra ini ada dua pendekatan yang dilakukan yaitu pelatihan serta bimbingan (pendampingan). Pelatihan dan bimbingan dilakukan dengan metode ceramah, diskusi, praktek lapangan, serta layanan konsultasi. Konsultasi dapat dilakukan melalui tatap muka, telepon ataupun melalui surat elektronik dan caracara lainnya yang mungkin dapat dilakukan. Untuk kesinambungan pembinaan, maka seyogyanya daerah ini dijadikan sebagai daerah binaan Universitas Andalas.

Secara umum tahapan kegiatan ini dapat dibagi dalam tiga kelompok utama sebagaimana yang dapat dilihat pada Gambar 1.

Pelaksanaan pelatihan dan bimbingan ditujukan untuk mendapatkan kapasitas kompos yang ideal berdasarkan investasi dan potensi yang ada serta untuk menghasilkan kualitas kompos yang baik. Lebih rinci dapat dirumuskan pada Tabel 1. 


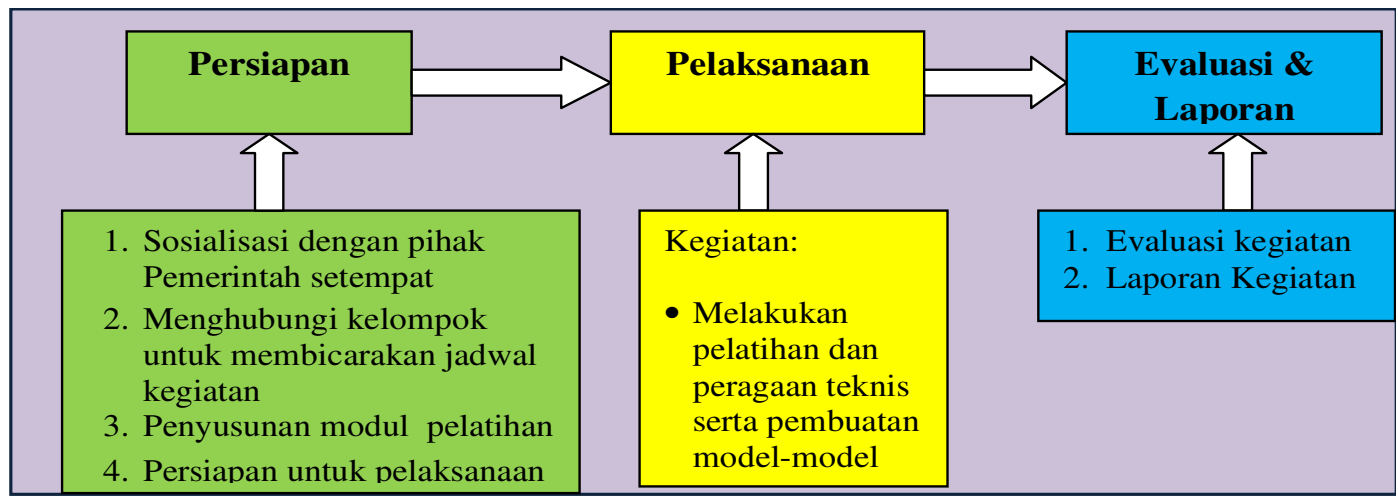

Gambar 1. Tahapan Kegiatan

Tabel 1. Rencana Pelatihan dan Bimbingan yang Akan Dilaksanakan

\begin{tabular}{|l|l|l|l|}
\hline No & $\begin{array}{l}\text { Permasalahan } \\
\text { Mitra }\end{array}$ & \multicolumn{1}{|c|}{ Solusi } & Kegiatan \\
\hline 1. & $\begin{array}{l}\text { Masih } \\
\text { rendahnya mutu } \\
\text { kompos yang } \\
\text { dihasilkan }\end{array}$ & $\begin{array}{l}\text { Perlu peningkatan pengetahuan dan teknik } \\
\text { pengomposan : } \\
\text { 1. Bahan baku kompos dan Starter yang bisa } \\
\text { digunakan } \\
\text { 2.knik pembuatan kompos untuk } \\
\text { menghasilkan kualitas kompos yang baik. }\end{array}$ & $\begin{array}{l}\text { Metode } \\
\text { pelatihan, } \\
\text { bimbingan } \\
\text { dan konsultasi }\end{array}$ \\
\hline 2. & $\begin{array}{l}\text { Belum mampu } \\
\text { melihat peluang } \\
\text { bisnis yang } \\
\text { besar dari } \\
\text { kompos }\end{array}$ & $\begin{array}{l}\text { Pengetahuan kewirausahaan dan melihat } \\
\text { potensi pasar dari produk kompos } \\
\text { 1. Isu pertanian berkelanjutan dan pentingnya } \\
\text { pupuk organik. } \\
\text { Teknik mempersiapkan kompos untuk } \\
\text { dipasarkan dan teknik memasarkan produk } \\
\text { kompos. }\end{array}$ & $\begin{array}{l}\text { Metode } \\
\text { bimbingan } \\
\text { dan konsultasi. }\end{array}$ \\
\hline 3 & $\begin{array}{l}\text { Belum } \\
\text { mengenal teknis } \\
\text { pembuatan } \\
\text { biogas yang } \\
\text { sederhana }\end{array}$ & $\begin{array}{l}\text { Peragaan pembuatan digseter untuk pembuatan } \\
\text { biogas berbahan baku kotoran sapi untuk skala } \\
\text { rumah tangga }\end{array}$ & $\begin{array}{l}\text { Penjelasan dan } \\
\text { Praktek }\end{array}$ \\
\hline 4 & $\begin{array}{l}\text { Belum kuatnya } \\
\text { kelembagaan } \\
\text { yang ada }\end{array}$ & $\begin{array}{l}\text { Perlu peningkatan kemampuan pengelolaan } \\
\text { kelembagaan, menyusun laporan keuangan } \\
\text { sederhana yaitu; Penyusunan 1) Buku Kas, 2) } \\
\text { Neraca dan 3) Laporan laba rugi serta teknik } \\
\text { pengelolaan kelembagaan dan efisiensi biaya } \\
\text { dalam kelompok. }\end{array}$ & $\begin{array}{l}\text { Metode } \\
\text { pelatihan, } \\
\text { bimbingan dan } \\
\text { konsultasi }\end{array}$ \\
\hline
\end{tabular}

Mitra mempunyai partisipasi mulai dari tahap persiapan, pelaksanaan dan evaluasi. Secara rinci keterlibatan mitra seperti Tabel 2. 
Tabel 2. Partisipasi Mitra

\begin{tabular}{|l|l|}
\hline \multicolumn{1}{|c|}{ Tahap Kegiatan } & \multicolumn{1}{c|}{ Partisipasi } \\
\hline Persiapan & $\begin{array}{l}\text { Kesepakatan kelompok dalam menetapkan anggota yang akan } \\
\text { dilibatkan dalam kegiatan }\end{array}$ \\
\hline Pelaksanaan & $\begin{array}{l}\text { 1. Mengikuti pelatihan dengan materi yang telah disiapkan tim. } \\
\text { 2. Keaktifan dalam mengemukakan permasalahan yang dihadapi } \\
\text { 3. Mempraktekan materi yang telah diajarkan dalam kegiatan } \\
\text { pelatihan. }\end{array}$ \\
& $\begin{array}{l}\text { 4. Menyediakan waktu yang cukup untuk melakukan konsultasi } \\
\text { 5. Menetapkan penempatan model digester biogas yang akan } \\
\text { diperagakan. }\end{array}$ \\
\hline Evaluasi dan Laporan & $\begin{array}{l}\text { 1. Mengikuti program evaluasi hasil kegiatan } \\
\text { 2. Menyampaikan perkembangan usaha dan permasalahan yang } \\
\text { dihadapi }\end{array}$ \\
\hline
\end{tabular}

KELAYAKAN PERGURUAN TINGGI

LPPM Universitas Andalas merupakan institusi organik yang bertugas mengelola seluruh kegiatan penelitian dan pengabdian kepada masyarakat, baik yang bersifat intra universitas maupun ekstra universitas (regional, nasional, dan internasional). LPPM Universitas Andalas memfasilitasi segala bentuk kegiatan kerjasama penelitian dan pengabdian kepada masyarakat, baik antar bidang ilmu maupun antar lembaga lembaga ini juga merupakan wadah bagi pembentukan berbagai pusat studi dan pusat kegiatan di lingkungan Universitas Andalas. Di samping itu, LPPM Universitas Andalas juga memfasilitasi berbagai pelatihan, workshop, dan pembekalan keilmuan dan praktik pengabdian.

Hasil IbPSNB yang dicapai oleh Lembaga Pengabdian pada Masyarakat Universitas Andalas adalah transformasi Ilmu Pengetahuan dan Teknologi (IPTEK) dan mewujudkan peningkatan keberdayaan masyarakat Desa Binaan secara terukur.
Hal ini dapat diketahui dari pelaksanaan IbPSNB dalam pemberdayaan masyarakat khususnya masyarakat petani melalui kegiatan pelatihan dan demonstrasi dalam menyelesaikan permasalahan masyarakat Desa Binaan.

Universitas Andalas memfasilitasi IbPSNB dengan berbagai fasilitas penunjang pendidikan maupun pelatihan dan pendampingan, seperti laboratorium : dasar (kimia, biologi, fisika, dan lain sebagainya), kimia dan biokimia hasil pertanian, teknologi dan rekayasa proses hasil pertanian, bioteknologi dan mikrobiologi hasil pertanian, instrumentasi, tanah, hama, penyakit, gulma dan pestisida, benih, kesuburan, pemetaan, teknologi pengolahan, laboratorium komputer dan lainnya. Disamping itu, Universitas Andalas juga memiliki fasilitas perpustakaan, unit pelaksanan teknis komputer. Hal ini cukup mendukung pelaksanaan kegiatan pelatihan dan pendampingan pada program pengabdian pada masyarakat. 
Semua kegiatan di atas dilaksanakan untuk meningkatkan pengetahuan dan pendapatan masyarakat serta akan berkelanjutan dalam jangka panjang. Hal ini didukung dengan Tim pengusul Program IbDM yang memiliki latar belakang yang saling menunjang dalam permasalahan yang dihadapi oleh masyarakat

Dengan melihat permasalahan yang ada di Jorong Koto Luar Kelurahan Limau Manis Selatan Kecamatan Pauh Kota Padang, maka jenis kepakaran yang diperlukan adalah:

a. Ilmu dan Teknologi Pangan

Rasional : Dengan metode ceramah akan diberikan pengetahuan awal bagi peserta manfaat pengolahan jagung menjadi produk olahan jagung dari segi kecukupan gizi maupun ketahanan pangan akibat pemanfaatan bahan baku lokal.

b. Teknologi Pengolahan Hasil Pertanian Rasional: Secara teknis kegiatan ini akan melakukan peningkatan nilai tambah produk pertanian berupa pengolahan jagung menjadi berbagai produk turunan jagung.

c. Teknologi Industri Pertanian

Rasional : Secara teknik akan didemonstrasikan teknologi pengolahan dan pengemasan pangan olahan jagung, teknik pelabelan hingga pemberian materi mengenai pengurusan izin edar.
Sehingga menjadi produk industri rumah tangga yang mampu bersaing nantinya.

d. Manajemen Industri

Rasional: Kelompok dan Petani jagung di Nagari Koto Tangah membutuhkan pengetahuan tentang aspek ekonomi usaha pertanian seperti analisa usaha ekonomi dan pemasaran produk. Mereka juga membutuhkan pengetahuan inovasi produk olahan jagung dan cara menangkap peluang sehingga dapat memberikan kontribusi ekonomi yang lebih besar terhadap pendapatan rumah tangga mereka.

Kualifikasi tim pelaksana yang diusulkan dalam program IbDM ini sesuai dengan jenis kepakaran yang diperlukan, sehingga keahlian tersebut diharapkan dapat mendukung keberhasilan program ini. Personil yang terlibat dalam kegiatan ini terdiri dari seorang koordinator pelaksana (Ketua Program Studi) beserta dengan 10 (sepuluh) orang anggota yang terdiri dari Dosen Fateta Unand serta dibantu oleh mahasiswa Fateta. Personil yang terlibat sekaligus akan menjadi instruktur yang melatih dan mendampingi petani mitra. Personil yang terlibat memiliki kompetensi sesuai dengan masalah-masalah prioritas yang akan ditangani pada Kelompok Mitra. 
HASIL DAN LUARAN YANG DICAPAI

Pengabdian masyarakat berlangsung dengan lancar Pendapatan Kelompok Tani di Jorong Koto Luar Kelurahan Limau Manis Selatan Kecamatan Pauh Kota Padang. Pengabdian masyrakat bekerja sama dengan LPMM Universitas Andalas, Dinas Pertanian Kabupaten Agam dan Kelompok Tani Batu Bajolang dan Kelompok Wanita Tani Sikayan Organik. Jumlah kumpulan anggota kelompok tani yang hadir berjumlah 20 orang.

Kegiatan penyuluhan yang dilakukan yaitu melakukan tinjauan kelompok tani pada tanggal 1 - 2 september 2017 beberapa anggota kelompok tani secara acak. Berdasarkan hasil tinjauan di lapangan Kelompok Tani Batu Bajolang mempunyai anggota sebanyak 40 orang dan Kelompok Wanita Tani Sikayan memiliki anggota sebanyak 20 orang. Kelompok Tani Batu Bajolang mengembangkan pertanian organik di lahan-lahan pertanian terutama untuk tanaman sayur-sayuran. Sementara itu Kelompok Wanita Tani Sikayan lebih fokus mengembangkan tanaman organik untuk tanaman pekarangan dengan komoditi sayur-sayuran, saledri, bawang daun dan strowbery. Kedua kelompok tani ini saling bekerjasama dimana Kelompok Tani Batu Bajolang memproduksi pupuk organik dan memproduksi beberapa jenis bibit tanaman. Pupuk organik yang dihasilkan juga digunakan oleh Kelompok Wanita Tani
Sikayan. Namun saja pupuk organik yang digunakan oleh kelompok tani selama ini hanya bersumber dari kotoran ternak sapi yang dikeringkan dengan tanpa ada perlakuan apa-apa. Disamping itu beberapa bibit tanaman yang dikembangkan oleh Kelompok Wanita Tani Sikayan juga disupplai oleh Kelompok Tani Batu Bajolang.

Penyuluhan mengenai pemanfaatan Jumlah sapi yang dimiliki anggota kelompok saaat ini berjumlah lebih kurang 80 ekor. Jika rata-rata 1 ekor sapi dapat menghasilkan kotoran sebanyak $15 \mathrm{~kg}$ per hari, maka dalam 1 hari akan diperoleh sebanyak lebih kurang $1.200 \mathrm{~kg}$ kotoran sapi basah atau lebih kurang 36 ton kotoran sapi basah per bulan. Seyogyanya kotoran sapi ini masih bisa ditambahkan dengan hijauan sisa makanan ternak yang biasanya masih tersisa antara 20 - $30 \%$ dari jumlah hijauan yang diberikan. Jika ditambahkan juga dengan limbah tanaman dalam jumlah yang sama kemudian dikeringkan dan dapat dihasilkan produk kompos, maka potensi kompos yang dihasilkan per bulannya lebih kurang 36 ton. Belum semua kotoran sapi dan limbah hasil pertanian dapat diolah menjadi kompos saat ini dikarenakan keterbatasan pengetahuan (teknologi) dan peralatan yang dimiliki oleh kelompok tani untuk memproduksi kompos. Jika 36 ton kompos kering bisa dihassilkan kelompok dalam 1 bulan dan harga jual kompos saat 
ini lebih kurang Rp. 625,- per kg, maka potensi pendapatan dari kompos kelompok tani di daerah ini lebih kurang sebesar Rp. 22.500.000,- per bulan.

Kotoran sapi yang dihasilkan sebelum dijadikan bahan baku kompos sebetulnya masih bisa dimanfaatkan terlebih dahulu sebagai sumber biogas. Biogas bisa dikembangkan pada setiap anggota kelompok yang memiliki sapi dan biogas yang dihasilkan bisa dimanfaatkan sebagai sumber bahan bakar pada rumah masingmasing rumah anggota.

Disamping memproduksi pupuk (kompos) organik dengan bahan baku kotoran sapi, kelompok ini juga mempunyai potensi untuk memproduksi pupuk (kompos) organik dengan bahan baku menggunakan kotoran ayam broiler. Di Kelurahan Limau Manis Selatan (khusus Jorong Kotobaru) terdapat 2 peternakan ayam broiler skala menengah dengan total kotoran yang dihasilkan lebih kurang 2 ton per hari.

Kegiatan pengabdian di Kelompok Tani di Jorong Koto Luar Kelurahan Limau Manis Selatan Kecamatan Pauh Kota Padang, telah dilaksanakan meliputi kegiatan sebagai berikut:

1. Pelatihan pembuatan pupuk kompos

2. Pelatihan merakit digester biogas khusus pada kelompok tani ternak sebanya 10 orang
3. Pelatihan melakukan operasional pengisian digester dan pemeliharaannya Dalam tahapan ini dilakukan tanya jawab antara tim pengabdian dengan peserta penyuluhan (kelompok tani). Kelompok wanita tani terlihat sangat serius dan antusias terhadap pelatihan pembuatan pupuk kompos, hal ini terlihat dari banyaknya pertanyaan yang diberikan oleh peserta.

Peragaan produk yang dilakukan yaitu diajarkan secara langsung kepada para peserta pelatihan pembuatan pupuk kompos dan pelatihan pembuatan biogas dari kotoran ternak melalui praktek dan latihan langsung pada satu orang petani yang akan dijadikan pilot proyek yang akan ditempatkan digester Biogas yaitu Armen. Penunjang peragaan pproduk ini tim memberikan bantuan alat-alat digester yang meliputi digester $1 \mathrm{~m}^{3}$ lengkap dengan alat penunjang seperti pipa inlet untuk memasukan kotoran ternak dan out let untuk mengeluarkan sisa kotoran dari digester serta selang, kran, dan alat bantu lainnya kepada sdr.Armen.

Luaran yang telah dicapai dari Program Ipteks Berbasis Prodi Dan Nagari Binaan (IbPSNB) ini adalah:

1. Kelompok Tani dan Kelompok wanita tani Jorong Koto Luar Kelurahan Limau Manis Selatan Kecamatan Pauh Kota Padang dapat memanfaatkan bahan baku kompos dan starter 
2. Kelompok Tani dan Kelompok wanita tani Jorong Koto Luar Kelurahan Limau Manis Selatan Kecamatan Pauh Kota Padang dapat membuat pupuk kompos sendiri dengan baik dan benar.

3. Dapat membuat Kemasan dan label yang telah didesain oleh tim Pengabdian Iptek berbasis Berbasis Prodi Dan Nagari Binaan (IbPSNB) berdampak pada produk pupuk yang dihasilkan telah mengapilkasikan teknologi pengemasan dan pelabelan yang tepat, sehingga dapat memudahkan dalam pengurusan izin usaha dan izin edar produk.

4. Kelompok Tani dan Kelompok wanita tani Jorong Koto Luar Kelurahan Limau Manis Selatan Kecamatan Pauh Kota Padang dapat membuat sendiri digester biogas dengan baik dan benar dapat memanfaatkan biogas untuk keperluan produktif dan konsumsi harian.

5. Dapat membuat Kemasan dan label yang telah didesain oleh tim Pengabdian Iptek berbasis Berbasis Prodi Dan Nagari Binaan (IbPSNB) berdampak pada produk pupuk yang dihasilkan telah mengapilkasikan teknologi pengemasan dan pelabelan yang tepat, sehingga dapat memudahkan dalam pengurusan izin usaha dan izin edar produk.

6. Luaran yang dicapai lainnya yaitu telah diterimanya tulisan tim pengabdian masyarakat yang berjudul Pelatihan Produksi Kompos Dan Biogas Di
Kelurahan Limau Manis Selatan Kota Padang pada jurnal Logista Fateta Unand dengan Volume 1 nomor 2 Tahun 2017 ISSN : 2579-6238.

\section{RENCANA TAHAPAN BERIKUTNYA}

Rencana tahapan program Pengabdian Iptek berbasis Berbasis Prodi Dan Nagari Binaan (IbPSNB) berikutnya dilakukan dalam bentuk tahapan sebagai berikut:

1. Tahapan pertama : Pelatihan perakitan dan pengoperasion digester biogas yang dirancang tim pengabdian Program Ipteks Berbasis Prodi Dan Nagari Binaan (IbPSNB)

2. Tahapan kedua: Penyuluhan dan Bantuan Pengurusan izin usaha dan izin edar produk. Bantuan dan bimbingan mengenai cara pengurusan pengurusan izin usaha dan izin edar produk produk pupuk kompos yang diproduksi oleh Kelompok Tani Batu Bajolang dan Kelompok Wanita Tani Sikayan Organik sehingga produk aman untuk diedarkan.

\section{Tahapan ketiga : Bantuan alat-alat}

Alat-alat yang diberikan kepada salah seorang dari kelompok tani adalah peralatan digester biogas.

\section{Tahapan Keempat : Monitoring dan Evaluasi}

Kegiatan ini bertujuan untuk memantau aktivitas mitra setelah tim pengabdian meninggalkan lokasi kelompok tani. Monitoring dan evaluasi dilakukan oleh Tim 
Pengadian masyarakat dengan turun langsung ke lokasi. Kegiatan monitoring dan evaluasi ini dilakukan dengan cara: mengadakan diskusi dengan kelompok tani, mengenai permasalahan yang dihadapi setelah kegiatan pendampingan, sehingga dicari pemecahan persoalan.

\section{KESIMPULAN DAN SARAN}

Kesimpulan yang bisa diambil dari Program Pengabdian Iptek berbasis Berbasis Prodi Dan Nagari Binaan (IbPSNB) pada Kelompok Tani dan Kelompok wanita tani Jorong Koto Luar Kelurahan Limau Manis Selatan Kecamatan Pauh Kota Padang ini yaitu :

1. Pengabdian masyarakat telah selesai dilaksanakan pada Pengabdian masyarakat bekerja sama dengan LPMM Universitas Andalas, dan Kelompok tani dan kelompok wanita tani di Jorong Koto Luar Kelurahan Limau manis Selatan Kota Padang.

2. Kelompok tani dan wanita tani jorong Koto Luar telah mendapatkan pengetahuan dan keterampilan mengenai teknik pembuatan pupuk kompos dengan pengemasan dan pelabelan yang sesuai standar yang diberikan penyuluhan dan peragaan langsung

3. Kelompok tani jorong Koto Luar telah mendapatkan keterampilan mengenai merakit digester biogas dan mengoperasikan digester dengan baik dan benar.

4. Luaran yang dicapai lainnya yaitu telah diterimanya tulisan tim pengabdian masyarakat yang berjudul Pelatihan Produksi Kompos Dan Biogas Di Kelurahan Limau Manis Selatan Kota Padang pada jurnal Logista Fateta Unand dengan Volume 1 nomor 2 Tahun 2017 ISSN : 2579-6238.

Saran dari tim Pengabdian Iptek berbasis Berbasis Prodi Dan Nagari Binaan (IbPSNB) pada Kelompok Tani dan Kelompok wanita tani Jorong Koto Luar Kelurahan Limau Manis Selatan Kecamatan Pauh Kota Padang, yaitu program pengabdian masyarakat sebaiknya dilakukan berkelanjutan setiap tahunnya sampai kelompok tani dan kelompok wanita tani sampai benar-benar bisa memproduksi produk yang telah dipraktekan sampai diterima dipasaran dan diproduksi secara masal.

\section{UCAPAN TERIMA KASIH}

Diucapkan terima kasih kepada Ketua Lembaga Penelitian dan Pengabdian Universitas Andalas bapak Dr.Ing.Uyung Gatot S Dinata,MT dan Bapak Dekan Fakultas Teknologi Pertanian Universitas Andalas atas dukungan moril dan bantuan materi yang diberikan sehingga terlaksananya kegiatan Pengabdian ini. 


\section{DAFTAR PUSTAKA}

Anonimous, 2006, Biogas Skala Rumah Tangga melalui Program Bio Energi Perdesaan (BEP), Ditjen PPHP-DEPTAN,Jakarta.

Arinal Hamni, 2008. Rancang Bangun dan Analisa Tekno Ekonomi Alat Biogas dari Kotoran Ternak Skala Rumah Tanga. Seminar Hasil Penelitian \& Pengabdian Kepada Masyarakat. Universitas Negeri Lampung

Badan Litbang Pertanian, 2010. Analisis Kebijakan Pertanian (Agricultural Policy Analysis)Pusat Analisis Sosial Ekonomi dan Kebijakan Pertanian. Badan Penelitian dan Pengembangan Pertanian Kementerian Pertanian.Volume 8 Nomor 3.
BPS. 2016. Berita Resmi Statistik No.41/7/13/Tahun XIX/1 Juli 2016. https://pariamankota.bps.go.id/websi teBackend/brs ind/brsInd20160714035727.pdf [Akses: 12 Mei 2017]

Richard Arthur, Martina Francisca Baidoo, Edward Antwi. 2011. Biogas as a potential renewable energy source: A Ghanaian case study. Renewable Energy, 36: pp. 1510-1516. DOI: 10.1016/j.renene.2010.11.012.

Sugi Rahayu, Dyah Purwaningsih, dan Pujianto. 2009. Pemanfaatan Kotoran Ternak Sapi Sebagai Sumber Energi Alternatif Ramah Lingkungan Beserta Aspek Sosio Kulturalnya Inotek 13(2): 15010Agustus 2009 